\title{
DAMPAK GUNCANGAN PERTUMBUHAN EKONOMI MITRA DAGANG UTAMA TERHADAP INDIKATOR MAKROEKONOMI INDONESIA
}

\author{
Yeny Puspita Ningsih ${ }^{1}$, Fitri Kartiasih ${ }^{2}$ \\ ${ }^{1}$ BPS RI; ${ }^{2}$ Politeknik Statistika STIS \\ Jln. Jl. Dr. Sutomo 6-8 Jakarta; Jln. Otto Iskandardinata Jakarta \\ E-mail : yeny.puspita@bps.go.id, fkartiasih@stis.ac.id \\ diterima: 22/2/2019; direvisi: 22/3/2019; diterbitkan: 31/3/2019
}

\begin{abstract}
Indonesia is one of the countries that implement open economic system. With many economic integration with other countries, external shocks will have an effect on Indonesia's macroeconomic stability. During the period of 2011-2015, Japan, China, and Singapore were Indonesia's main trading partners in both export and import. Since 2010 the economy of the three countries has slowdown shock which showed by decreasing in economic growth. Due to the size of Indonesia's dependence on Japan, China, and Singapore in the trade sector, the shocks are feared not only affect to the trade performance, but also to other macroeconomics. This study aims to analyze the impact of economic growth shocks of main trading partner on Indonesia's macroeconomic indicators which include exports, GDP, and employment in 19862015. The method used is Vector Autoregression (VAR)/Vector Error Correction Model (VECM). The IRF results show that Indonesia's macroeconomic indicators provide a positive response to the economic growth shocks of main trading partners, the decreasing in economic growth in China, Singapore and Japan will impact the decrease in export growth, GDP and employment of Indonesian. The FEVD results indicate that the economic growth shocks of main trading partners have contributed substantially to the variability of Indonesia's macroeconomic indicators.
\end{abstract}

Keywords: External shock, macroeconomic, response, VAR/VECM

\section{PENDAHULUAN}

Keterbukaan sistem ekonomi yang dimiliki sebuah negara turut berpengaruh terhadap kemajuan perekonomian negara tersebut (Retnasih, Agustin, dan Wulandari, 2016). Semakin terbuka sistem perekonomian suatu negara, peluang untuk melakukan kerja sama dengan negara lain akan semakin besar. Indonesia merupakan salah satu negara yang menerapkan sistem perekonomian terbuka. Dengan banyaknya integrasi ekonomi yang dijalin oleh Indonesia dengan negara lain, kejadian ekonomi yang terjadi secara global akan memberikan pengaruh terhadap stabilitas makroekonomi Indonesia baik secara langsung maupun tidak langsung (Setiawan, 2010). Seperti pada krisis ekonomi periode 1997-1998 dan 2008 yang berdampak pada melemahnya perekonomian Indonesia.

Dampak krisis dapat menyebar ke negara lain termasuk Indonesia melalui berbagai jalur, diantaranya jalur investasi, remiten, dan perdagangan (Ramana, 2016). Menurut Tambunan (2010), jalur transmisi yang paling dominan bagi Indonesia adalah jalur perdagangan. Penelitian yang dilakukan Ramana juga menyimpulkan bahwa transmisi melalui jalur perdagangan lebih berpengaruh dibandingkan dengan jalur investasi. Hal ini didukung dengan derajat keterbukaan Indonesia yang cukup besar, yakni sebesar 48,06 persen pada tahun 2014 (World Bank, 2016), yang berarti total nilai ekspor dan impor Indonesia mencapai 48,06 persen dari total Produk Domestik Bruto (PDB) Indonesia sehingga tidak mengherankan jika jalur 
perdagangan menjadi jalur transmisi yang paling berpengaruh.

Indonesia melakukan

perdagangan internasional dengan berbagai negara di dunia. Berdasarkan data Badan Pusat Statistik, selama periode 2011-2015, mitra dagang yang menjadi tujuan utama ekspor Indonesia berturut-turut adalah Jepang (14,46 persen), Tiongkok (11,07 persen), dan Singapura (9,05 persen). Ekspor Indonesia ke tiga negara tersebut mencapai lebih dari 30 persen dari total ekspor Indonesia. Dari sisi impor, Jepang, Tiongkok, dan Singapura juga menempati posisi teratas sebagai negara asal utama impor Indonesia. Impor Indonesia dari tiga negara tersebut mencapai lebih dari 40 persen dari total impor Indonesia. Dari uraian tersebut, Indonesia memiliki ketergantungan yang cukup besar terhadap tiga negara tersebut di sektor perdagangan, baik dari sisi ekspor maupun impor, sehingga negara yang menjadi mitra dagang utama dalam penelitian ini adalah Jepang, Tiongkok, dan Singapura.

Beberapa tahun terakhir, kondisi perekonomian dunia tidak stabil sehingga menyebabkan pelemahan ekonomi di banyak negara, tidak terkecuali mitra dagang utama Indonesia. Selama periode 1986-2009, perkembangan pertumbuhan ekonomi mitra dagang utama Indonesia cukup berfluktuasi, bahkan Singapura dan Jepang beberapa kali mengalami pertumbuhan ekonomi yang negatif. Namun, sejak tahun 2010 perekonomian ketiga mengalami guncangan pelemahan yang ditandai dengan menurunnya pertumbuhan ekonomi. Berdasarkan data World Bank, pertumbuhan ekonomi Tiongkok tahun 2010 adalah sebesar 10,64 persen dan menurun menjadi 6,91 persen pada tahun 2015. Demikian pula dengan Jepang, yang mengalami penurunan dari 4,19 persen menjadi 1,22 persen. Penurunan pertumbuhan ekonomi yang dialami oleh Singapura paling signifikan dibandingkan dengan dua mitra dagang lainnya yakni dari 15,24 persen menjadi 2,01 persen pada tahun 2015. Perkembangan pertumbuhan ekonomi ketiga mitra dagang tersebut selama periode 2010-2015 mengindikasikan bahwa pertumbuhan ekonomi mitra dagang utama Indonesia sedang mengalami guncangan.

Guncangan

penurunan pertumbuhan ekonomi mitra dagang utama Indonesia ternyata diikuti dengan penurunan kinerja ekspor Indonesia. Menurut data BPS, selama periode 2011 sampai 2015, ekspor Indonesia ke tiga mitra dagang tersebut cenderung mengalami penurunan. Ekspor Indonesia ke Jepang pada tahun 2011 adalah sebesar 33.714,67 juta USD dan mengalami penurunan hampir 50 persennya hingga menjadi $18.020,88$ juta USD pada tahun 2015. Demikian pula dengan ekspor ke Tiongkok dan Singapura yang mengalami penurunan, masing-masing sebesar 7.444,57 juta USD dan 5.811,26 juta USD. Karena besarnya ketergantungan Indonesia terhadap Jepang, Tiongkok, dan Singapura di sektor perdagangan, guncangan tersebut dikhawatirkan tidak hanya berpengaruh terhadap kinerja ekspor, tetapi juga indikator makroekonomi Indonesia lainnya. Beberapa pihak memprediksi guncangan tersebut masih akan berlanjut. Oleh karena itu, peneliti tertarik untuk meneliti dampak guncangan pertumbuhan ekonomi mitra dagang terhadap indikator makroekonomi Indonesia tahun 19862015.

\section{TINJAUAN PUSTAKA}

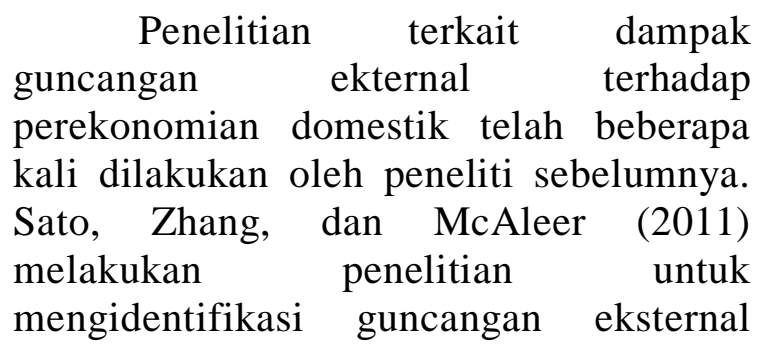


Jurnal Ilmiah Ekonomi dan Bisnis

Vol. 16. No.1, Maret 2019: 78-92

EISSN : $2442-9813$

ISSN : $1829-9822$

pada perekonomian sepuluh negara di kawasan regional Asia Timur dengan menggunakan metode structural Vector Autoregression (SVAR). Variabel external shock pada penelitian ini adalah harga minyak dunia, pertumbuhan PDB riil Amerika Serikat, Jepang, dan China. Sedangkan variabel penerima shock adalah pertumbuhan PDB riil dan tingkat inflasi di sepulih negara tersebut. Bounchaour dan Hussein (2012) juga melakukan penelitian serupa mengenai dampak fluktuasi harga minyak dunia terhadap makroekonomi Algeria tahun 1980-2011 dengan menggunakan model Vector Error Correction Model (VECM). Variabel makroekonomi dalam penelitian tersebut meliputi PDB riil, pengangguran, inflasi, nilai tukar riil, dan jumlah uang beredar.

Selanjutnya, Bermingham dan Conefrey (2014) juga melakukan penelitian serupa mengenai respon indikator makroekonomi Irlandia terhadap guncangan eksternal dengan menggunakan Bayesian VAR. Guncangan eksternal pada penelitian ini adalah pertumbuhan PDB mitra dagang utama Irlandia, yakni Amerika Serikat, Inggris, dan kawasan Eropa. Sedangkan, variabel makroekonomi penerima guncangan adalah pertumbuhan PDB, ekspor, tingkat pengangguran, dan upah. Hasil analisis Impulse Response Function menujukkan bahwa guncangan pertumbuhan PDB mitra dagang akan direspon positif oleh ekspor, pertumbuhan PDB, dan upah serta direspon negatif oleh tingkat pengangguran. Guncangan eksternal yang paling berpengaruh terhadap makroekonomi Irlandia berasal dari negara kawasan Eropa.

Penelitian ini juga akan menggunakan analisis time series yaitu model Vector Autoregression (VAR). Model VAR digunakan karena mampu menangkap fenomena ekonomi yang terjadi terkait respon indikator makroekonomi Indonesia ketika terjadi guncangan (shock) pada pertumbuhan ekonomi mitra dagang utama. Variabel yang digunakan dalam penelitian ini mengacu pada penelitian yang dilakukan oleh Bermingham dan Conefrey (2014). External shock atau variabel yang mengalami guncangan pada penelitian ini adalah pertumbuhan ekonomi mitra dagang utama Indonesia, yaitu Tiongkok, Singapura, dan Jepang. Sedangkan, variabel penerima shock adalah indikator makroekonomi Indonesia yang meliputi ekspor, Produk Domestik Bruto, dan penyerapan tenaga kerja.

Adapun tujuan dalam penelitian ini antara lain: (1) mengetahui gambaran perkembangan pertumbuhan ekonomi mitra dagang utama dan indikator makroekonomi Indonesia; menganalisis respon indikator makroekonomi Indonesia terhadap guncangan pertumbuhan ekonomi mitra dagang utama; (3) menganalisis kontribusi pertumbuhan ekonomi mitra dagang utama terhadap variabilitas indikator makroekonomi Indonesia.

\section{METODE PENELITIAN}

Data yang digunakan dalam penelitian ini adalah data runtun waktu (time series) periode tahunan yakni dari tahun 1986-2015. Data tersebut merupakan data sekunder yang diperoleh dari Badan Pusat Statistik (BPS) dan Bank Dunia (World Bank). Data yang digunakan dalam penelitian ini terdiri dari:

1. Data Produk Domestik Bruto Indonesia atas dasar harga konstan 2010 tahunan (1986-2015) dalam satuan Dollar Amerika Serikat (USD) yang diperoleh dari publikasi World Bank.

2. Data pertumbuhan ekonomi Tiongkok, Singapura, dan Jepang periode tahunan (1986-2015) dalam persen yang diperoleh dari publikasi World Bank. 
3. Nilai ekspor Indonesia periode tahunan (1986-2015) dalam satuan juta Dollar Amerika Serikat (juta USD) yang diperoleh dari publikasi Badan Pusat Statistik.

4. Data jumlah penduduk yang bekerja periode tahunan (19862015) dalam satuan orang yang diperoleh dari publikasi Badan Pusat Statistik.

Metode analisis yang digunakan dalam penelitian ini adalah analisis desktiptif dan analisis inferensia yang berupa analisis time series. Analisis deskriptif dalam penelitian ini digunakan untuk memberikan gambaran umum mengenai perkembangan pertumbuhan ekonomi mitra dagang utama Indonesia serta perkembangan indikator makroekonomi Indonesia yang meliputi ekspor, Produk Domestik Bruto, dan penyerapan tenaga kerja tahun 19862015 dengan menggunakan grafik.

Adapun analisis time series dalam penelitian ini menggunakan model Vector Autoregression (VAR)/Vector Error Correction Model (VECM) dengan dua alat analisis utama yaitu Impulse Response Function (IRF) dan Forecast Error Variance Decomposition (FEVD). Alasan yang melatarbelakangi penggunaan model VAR/VECM diantaranya: mengacu pada penelitian terdahulu yang dilakukan oleh Nizar (2012) serta Bounchaour dan Hussein (2012); jumlah variabel penerima guncangan atau variabel endogen dalam penelitian ini ada tiga; dan tujuan dari penelitian ini adalah untuk menangkap fenomena ekonomi yang terjadi yakni respon indikator makroekonomi terhadap guncangan pertumbuhan ekonomi mitra dagang utama dan hal ini dapat tergambarkan melalui analisis IRF dalam VAR. Selain itu, menurut Gujarati (2004), VAR memiliki beberapa keunggulan, diantaranya: metode VAR sederhana karena tidak perlu menentukan variabel endogen dan eksogen, metode estimasinya sederhana, dan hasil peramalan dalam banyak kasus lebih baik dibandingkan dengan model persamaan simultan yang kompleks.

Pada penelitian ini, guncangan dari setiap mitra dagang akan dimodelkan tersendiri dengan menggunakan variabel penerima guncangan yang sama, sehingga akan terbentuk tiga model, yakni model Jepang, model Tiongkok, dan model Singapura. Adapun tahapan pembentukan model VAR/VECM untuk masing-masing model adalah sebagai berikut:

1. Melakukan uji stasioneritas pada data yang digunakan untuk mengetahui apakah mengandung akar unit atau tidak. Pada penelitian ini digunakan uji stasioneritas menggunakan uji Phillip-Perrons (PP). Beberapa kemungkinan yang dapat terjadi berdasarkan hasil uji stasioneritas:

a. Jika semua variabel stasioner pada level maka digunakan model VAR in level.

b. Jika variabel tidak stasioner pada level, maka dilakukan diferensiasi sampai semua variabel stasioner pada difference yang sama.

2. Menentukan jumlah lag yang optimal untuk model. Penentuan lag optimal pada penelitian ini didasarkan pada kriteria Final Prediction Error (FPE) atau Akaike Information Criterion (AIC). Lag yang memiliki nilai terkecil pada kedua atau salah satu kriteria tersebut akan terpilih sebagai lag optimal.

3. Selanjutnya dilakukan pengujian stabilitas model VAR yang terbentuk. Pengujian stabilitas VAR dapat dilihat berdasarkan roots of characteristic polynomial. Jika semua akar dari fungsi polinomial memiliki nilai kurang 
Jurnal Ilmiah Ekonomi dan Bísnis

Vol. 16. No.1, Maret 2019: 78-92

EISSN : $2442-9813$

ISSN : $1829-9822$

dari satu atau berada dalam unit circle, maka dapat dikatakan bahwa model VAR yang terbentuk sudah stabil.

4. Jika tidak semua variabel stasioner pada level tetapi semuanya stasioner pada first difference, maka perlu dilakukan uji kointegrasi. Uji kointegrasi dalam penelitian ini menggunakan

Johansen

Cointegration Test. Ada beberapa kemungkinan berdasarkan hasil uji kointegrasi:

a. Jika terdapat kointegrasi, maka model yang digunakan adalah VECM.

b. Jika tidak terdapat kointegrasi, maka model yang digunakan adalah VAR first difference.

5. Setelah terpilih model yang tepat, langkah selanjutnya yaitu menganalisis Impulse Response Function (IRF) dan Forecast Error Variance Decomposition (FEVD) yang terbentuk.

\section{HASIL DAN PEMBAHASAN}

Pertumbuhan ekonomi pada penelitian ini merupakan persentase kenaikan PDB riil pada suatu tahun tertentu dibandingkan dengan PDB riil pada tahun sebelumnya. Berdasarkan Gambar 1, perkembangan pertumbuhan ekonomi mitra dagang utama Indonesia selama periode 1986-2015 cukup berfluktuasi. Rata-rata pertumbuhan ekonomi mitra dagang yang paling tinggi adalah Tiongkok yakni sebesar 9,65 persen. Kemudian di posisi kedua dan ketiga adalah Singapura dan Jepang dengan rata-rata 6,47 persen dan 1,67 persen.

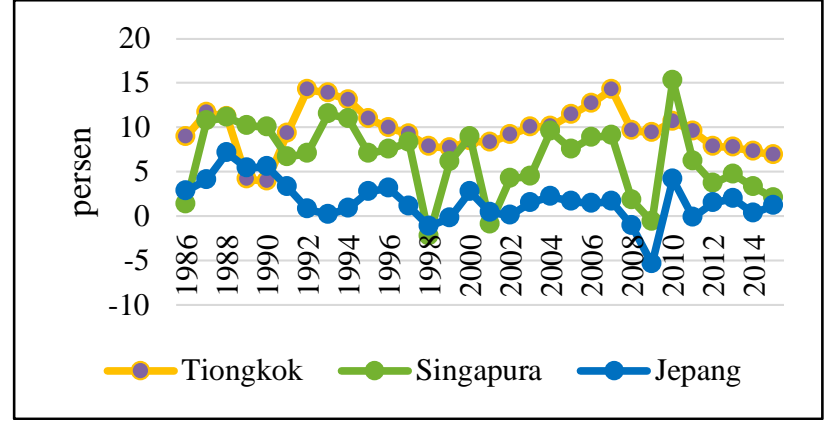

Sumber: World Bank (diolah)

Gambar 1.

Pertumbuhan ekonomi mitra dagang utama Indoneia tahun 1986-2015

Pertumbuhan ekonomi ketiga mitra dagang mengalami penurunan yang cukup signifikan akibat krisis ekonomi tahun 1997/1998 dan krisis global tahun 2008. Bahkan, pertumbuhan ekonomi Singapura dan Jepang menjadi negatif pada tahun 1998 dan 2009. Setelah periode krisis, pertumbuhan ekonomi ketiga mitra dagang mengalami peningkatan. Namun, sejak tahun 2010, perkembangan pertumbuhan ekonomi mitra dagang utama cenderung menurun. Pertumbuhan ekonomi Tiongkok menurun dari 10,64 persen pada tahun 2010 menjadi 6,91 persen pada tahun 2015. Demikian pula dengan Jepang yang mengalami penurunan dari 4,19 persen menjadi 1,22 persen. Penurunan pertumbuhan ekonomi Singapura paling signifikan, yakni dari 15,24 persen menjadi 2,01 persen pada tahun 2015. Secara umum, guncangan penurunan pertumbuhan ekonomi mitra dagang ini dikarenakan oleh kondisi perekonomian global yang tidak stabil sehingga berdampak pada menurunnya permintaan global dan harga berbagai komoditas.

Gambaran Umum Perkembangan Ekspor Indonesia

Ekspor yang dicakup dalam penelitian ini meliputi ekspor barang, baik migas maupun non-migas. Berdasarkan Gambar 2, selama periode 1986-2015 nilai dan volume ekspor Indonesia mempunyai pergerakan yang hampir 
sama, yakni cenderung meningkat kemudian menurun. Namun, pada tahun 2012 dan 2013 terjadi perbedaan pergerakan, dimana volume ekspor mengalami peningkatan, tetapi nilainya menurun. Hal ini disebabkan menurunnya harga berbagai komoditas ekspor di pasar dunia. Variabel yang digunakan dalam penelitian ini adalah nilai ekspor, sehingga pada bagian ini akan difokuskan untuk menganalisis nilai ekspor.

Nilai ekspor Indonesia cenderung meningkat dari tahun 1986 sampai 2011, kemudian mulai mengalami tren menurun sejak tahun 2011 sampai 2015. Pada tahun 1986, ekspor Indonesia adalah sebesar 14.805 juta USD dan meningkat lebih dari sepuluh kali lipat menjadi $150.366,3$ juta USD pada tahun 2015. Krisis ekonomi 1997/1998 dan krisis global 2008 turut berdampak pada menurunnya nilai ekspor Indonesia. Sejak tahun 2011, perkembangan ekspor Indonesia mengalami penurunan yang cukup signifikan yakni dari 203.496,6 juta USD menjadi $150.366,3$ juta USD pada tahun 2015. Penurunan ini disebabkan oleh melemahnya kondisi perekonomian beberapa mitra dagang Indonesia sehingga permintaan ekspor Indonesia menurun dan menurunnya harga beberapa komoditas ekspor. Selain itu, juga dikarenakan rendahnya daya saing produk Indonesia dibandingkan dengan negara lain.

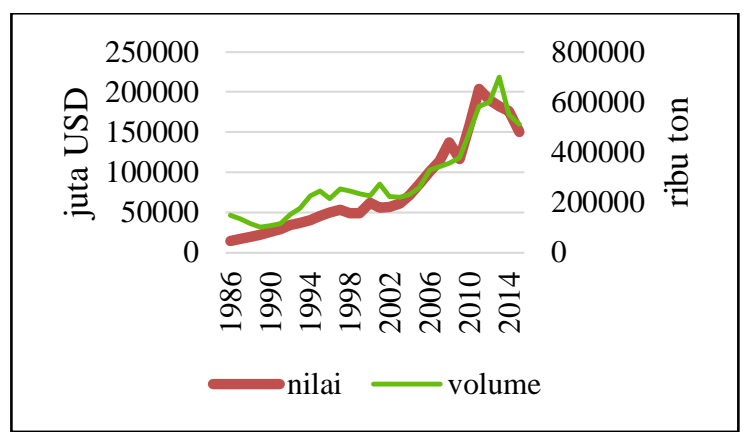

Sumber: Badan Pusat Statistik (diolah)

Gambar 2. Nilai dan volume ekspor Indonesia tahun 1986-2015 (juta USD)
Gambaran Umum Perkembangan Produk Domestik Bruto Indonesia

Berdasarkan Gambar 3, perkembangan Produk Domestik Bruto (PDB) Indonesia atas dasar harga konstan 2010 atau PDB riil selama periode 19862015 cenderung mengalami peningkatan dari tahun ke tahun. Besarnya PDB riil Indonesia pada tahun 1986 adalah 242.227,89 juta USD dan mengalami peningkatan hampir empat kali lipat menjadi $988.127,96$ juta USD pada tahun 2015. Rata-rata PDB riil Indonesia selama periode 1986-2015 adalah sebesar 533.314,26 juta USD. Sedangkan, pertumbuhan PDB riil Indonesia cukup berfluktuasi selama periode 1986-2015, dengan rata-rata sebesar 4,87 persen.

Krisis ekonomi tahun 1997/1998 memberikan dampak yang signifikan terhadap perkembangan PDB riil Indonesia, yakni menurun dari 493.545,85 juta USD pada tahun 1997 menjadi 428.759,44 juta USD pada tahun 1998 atau menurun sekitar 13 persen. Sedangkan, krisis global 2008 tidak berdampak pada menurunnya PDB riil, tetapi hanya berdampak pada penurunan pertumbuhan PDB riil, yakni menurun sekitar 1,38 persen pada tahun 2009. Setelah krisis global, PDB rill Indonesia terus mengalami peningkatan. Meskipun PDB riil meningkat, pertumbuhan PDB riil Indonesia mengalami gejala pelemahan sejak tahun 2010. Pertumbuhan PDB riil Indonesia mengalami penurunan dari 6,22 persen pada tahun 2010 menjadi 4,88 persen pada tahun 2015. Hal ini disebabkan lesunya perekonomian global sehingga permintaan ekspor turun serta penurunan konsumsi domestik. 


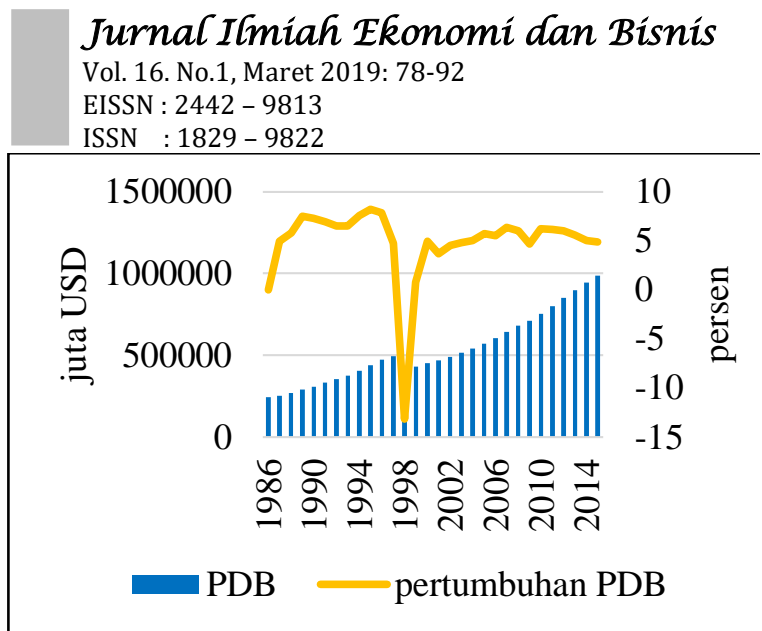

Sumber: World Bank (diolah)

Gambar 3.

Produk Domestik Bruto dan pertumbuhan Produk Domestik Bruto Indonesia atas dasar harga konstan 2010 tahun 1986-2015

Gambaran Umum Penyerapan Tenaga Kerja Indonesia

Menurut Boediono dalam Zamrowi (2007), penyerapan tenaga kerja didefinisikan jumlah tenaga kerja yang bekerja dalam suatu unit usaha. Berdasarkan definisi tersebut, penyerapan tenaga kerja pada penelitian ini didekati dengan konsep BPS yakni jumlah penduduk usia kerja (15 tahun ke atas) yang bekerja. Berdasarkan Gambar 4, perkembangan penyerapan tenaga kerja di Indonesia tahun 1986-2015 memiliki tren yang positif atau cenderung mengalami peningkatan dari tahun ke tahun. Jumlah tenaga kerja yang terserap pada tahun 1986 adalah sebesar 65,38 juta orang dan meningkat hampir dua kali lipat menjadi 114,82 juta orang pada tahun 2015. Rata-rata jumlah tenaga kerja yang terserap setiap tahunnya selama periode 1986-2015 adalah sekitar 90,15 juta orang.

Pertumbuhan penyerapan tenaga kerja selama periode 1986-2015 cukup berfluktuasi dengan rata-rata sebesar 1,96 persen. Berbeda dengan dua indikator makroekonomi lainnya, krisis ekonomi 1997/1998 dan krisis global 2008 tidak berdampak langsung pada menurunnya penyerapan tenaga kerja, melainkan berdampak pada penurunan pertumbuhan penyerapan tenaga kerja. Meskipun jumlah tenaga kerja yang terserap meningkat dari tahun ke tahun, pertumbuhan penyerapan tenaga kerja mengalami penurunan yang cukup signifikan sejak tahun 2012 sampai 2015.

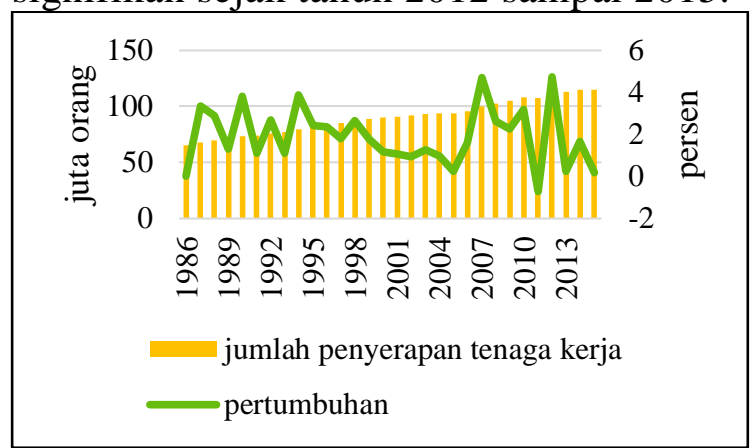

Sumber: Badan Pusat Statistik (diolah) Gambar 4.

Jumlah dan pertumbuhan penyerapan tenaga kerja Indonesia tahun 1986-2015

\section{Analisis Time Series}

Tahap awal dalam dalam analisis time series adalah melakukan pengujian pra-estimasi, yang meliputi: uji stasioneritas, penentuan lag optimal, pengujian stabilitas VAR, dan uji kointegrasi.

\section{Uji Stasioneritas}

Uji Stasioneritas digunakan untuk menentukan apakah suatu data mengandung akar unit atau tidak. Metode yang digunakan adalah uji PhillipsPerron $(P P)$. Jika t-statistik lebih kecil dibandingkan dengan nilai kritis MacKinnon, maka $H_{0}$ ditolak dan dapat disimpulkan bahwa data stasioner (tidak mengandung akar unit).

Tabel 1. Hasil pengujian stasioneritas

\begin{tabular}{|l|l|l|l|l|}
\hline \multirow{2}{*}{ ariabel } & \multicolumn{3}{|c|}{ Level } & \multicolumn{2}{c|}{ Difference } \\
\cline { 2 - 5 } & -statistik & robalilitas & -statistik & robalilitas \\
\hline $\mathrm{1})$ & 2 ) & $3)$ & $4)$ & $5)$ \\
\hline $\mathrm{T}$ & 1,894020 &, 3303 & 6,447683 &, 0000 \\
\hline $\mathrm{J}$ & 3,469266 &, 0164 & 15,70393 &, 0000 \\
\hline $\mathrm{S}$ & 1,777326 &, 0720 & 12,50795 &, 0000 \\
\hline $\mathrm{NX}$ & 1,834902 &, 3569 & 4,453757 &, 0015 \\
\hline $\mathrm{NPDB}$ & 0,451254 &, 8870 & 3,784455 &, 0080 \\
\hline $\mathrm{NKRJ}$ & 1,793708 &, 3760 & 6,456099 &, 0000 \\
\hline
\end{tabular}


Nilai kritis MacKinnon dengan $\alpha$ $=5$ persen pada tingkat level adalah 2,967767 . Hasil pengujian pada Tabel 1, semua variabel tidak stasioner pada alpha 5 persen, kecuali variabel pertumbuhan ekonomi Jepang (GJ). Oleh karena itu, pengujian stasioneritas perlu dilanjutkan pada tingkat first difference. Pada tingkat first difference nilai t-statistik semua variabel lebih kecil dibandingkan dengan nilai kritis MacKinnon pada $\alpha=5$ persen yang sebesar -2,971853, sehingga dapat disimpulkan bahwa semua variabel sudah stasioner pada tingkat first difference.

\section{Penentuan Lag Optimal}

Penentuan lag optimal dalam pendekatan VAR sangat penting karena lag dari variabel endogen dalam sistem persamaan akan dijadikan sebagai variabel eksogen. Pada model Tiongkok, lag maksimal yang didapat adalah 3, sehingga untuk mencari lag optimal digunakan sampai dengan lag 3. Berdasarkan Tabel 2, kandidat lag optimal yang terpilih menurut kriteria FPE dan AIC untuk model Tiongkok adalah lag 2, sebagaimana yang ditunjukkan dengan tanda (*). Menurut Lutkepohl (2005), ketika pengujian lag optimal menggunakan variabel yang belum stasioner, maka untuk pengujian kointegrasi dan estimasi persamaan VECM selanjutnya digunakan lag (p-1), atau dalam hal ini adalah lag 1.

Tabel 2. Hasil pengujian lag optimal untuk model Tiongkok, Singapura, dan Jepang

\begin{tabular}{|l|l|l|l|l|l|l|}
\hline \multirow{2}{*}{} & \multicolumn{2}{|l|}{ Model Tiongkok } & \multicolumn{2}{l|}{ Model Singapura } & \multicolumn{2}{l|}{ Model Jepang } \\
\cline { 2 - 7 } & PE & IC & PE & IC & PE & IC \\
\hline &, $75 \mathrm{E}-06$ & 0,187134 &, $39 \mathrm{E}-07$ & 4,439457 &, $08 \mathrm{E}-08$ & 5,944105 \\
\hline &, $70 \mathrm{E}-08$ & 6,09354 & $\begin{array}{l}5,68 \mathrm{e}- \\
08^{*}\end{array}$ & $-5,353820^{*}$ & $\begin{array}{l}2,37 \mathrm{e}- \\
08^{*}\end{array}$ & 6,229182 \\
\hline & $\begin{array}{l}2,02 \mathrm{e}- \\
08^{*}\end{array}$ & $-6,469995^{*}$ &, $66 \mathrm{E}-08$ & 5,04543 &, $82 \mathrm{E}-08$ & 5,630752 \\
\hline &, $86 \mathrm{E}-08$ & 6,066416 &, $34 \mathrm{E}-07$ & 4,925405 &, $21 \mathrm{E}-08$ & 5,869197 \\
\hline & &, $85 \mathrm{E}-07$ & 5,346628 &, $53 \mathrm{E}-08$ & $-6,751119^{*}$ \\
\hline
\end{tabular}

Pada model Singapura dan Jepang, lag maksimal yang diperoleh adalah lag 4 . Kandidat lag optimal yang terpilih untuk kedua model tersebut adalah lag 1 . Karena pengujian dilakukan pada variabel first difference atau yang sudah stasioner, maka untuk pengujian kointegrasi dan estimasi persamaan tidak perlu dikurangi 1. Dari uraian di atas, lag optimal yang digunakan pengujian kointegrasi dan estimasi persamaan selanjutnya untuk ketiga model adalah lag 1. Penggunaan lag 1 berarti bahwa variabel-variabel yang terdapat dalam model tidak hanya berkaitan pada periode sekarang, tetapi juga saling berkaitan pada satu tahun sebelumnya.

\section{Uji Stabilitas Model VAR}

Model VAR perlu diuji stabilitasnya untuk memastikan Impulse Response Function (IRF) dan Forecasting Error Variance Decomposition (FEVD) yang terbentuk valid. Pengujian stabilitas VAR dapat dilihat berdasarkan roots of characteristic polynomial.

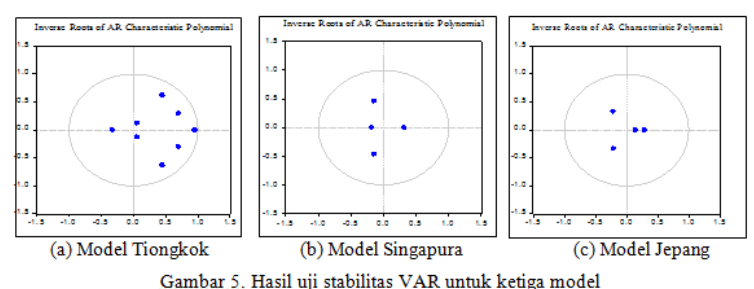

(a) Model Tiongkok

(b) (b) Model Singapura

(c) (c) Model Jepang

Gambar 5.

Hasil uji stabilitas VAR untuk ketiga model

Berdasarkan Gambar 5, semua root untuk model Tiongkok, Singapura, maupun Jepang berada di dalam unit circle atau memiliki modulus yang kurang dari satu, sehingga dapat disimpulkan bahwa model VAR yang terbentuk sudah stabil pada lag optimalnya. 
Jurnal Ilmiah Ekonomi dan Bisnis

Vol. 16. No.1, Maret 2019: 78-92

EISSN : $2442-9813$

ISSN : $1829-9822$

Uji Kointegrasi

Uji kointegrasi dilakukan untuk mengetahui apakah terdapat kointegrasi atau hubungan jangka panjang di antara variabel yang tidak stasioner. Pada penelitian ini, metode pengujian kointegrasi yang digunakan adalah Johansen's Cointegration Test. Menurut Enders (2004), jika terdapat kointegrasi di antara variabel penelitian maka model estimasi yang digunakan adalah model Vector Error Correction Model (VECM). Sedangkan, jika tidak terdapat kointegrasi, maka estimasi dilakukan dengan menggunakan model VAR in difference.

Langkah awal dalam uji kointegrasi adalah menentukan model yang tepat. Berdasarkan Lampiran 1, asumsi deterministic trend yang terpilih menurut kriteria AIC dan SC untuk ketiga model adalah asumsi yang kedua, yakni data atau persamaan VAR tidak mempunyai tren dan persamaan kointegrasi mempunyai intersep. Selanjutnya dilakukan pengujian untuk menentukan jumlah kointegrasi berdasarkan trace statistic dan maxeigen statistic. Menurut Lutkepohl, Pentti, dan Carsten (2002), dalam sampel kecil trace statistic mempunyai kekuatan yang lebih tangguh dibandingkan max-eigen statistic, sehingga penelitian ini mengacu pada hasil trace statistic.

Berdasarkan Tabel 3, nilai trace statistic pada model Tiongkok dan Singapura lebih besar dibandingkan nilai critical value untuk hipotesis nol: $r=0$, sehingga dapat disimpulkan bahwa terdapat satu kointegrasi pada taraf nyata 5 persen. Karena terdapat kointegrasi, maka model yang tepat untuk Tiongkok dan Singapura adalah VECM. Sedangkan, pada model Jepang, nilai trace statistic lebih kecil dibandingkan nilai critical value untuk semua hipotesis nol, sehingga dapat disimpulkan bahwa tidak terdapat kointegrasi. Karena data stasioner pada first difference, namun tidak terjadi kointegrasi maka model yang tepat untuk Jepang adalah VAR first difference.

Tabel 3. Hasil uji kointegrasi untuk model Tiongkok, Singapura, dan Jepang

\begin{tabular}{|c|c|c|c|c|c|}
\hline odel & $\begin{array}{l}\text { ipotesis } \\
\text { Nol }\end{array}$ & $\begin{array}{l}\text { race } \\
\text { Statistic }\end{array}$ & $\begin{array}{l}\text {,05 } \\
\text { Critical } \\
\text { Value }\end{array}$ & $\begin{array}{l}\text { ax-Eigen } \\
\text { Statistic }\end{array}$ & $\begin{array}{l}, 05 \\
\text { Critical } \\
\text { Value }\end{array}$ \\
\hline \multirow{2}{*}{ iongkok } & $r=0^{*}$ & 1,67668 & 4,07904 & 3,29182 & 8,58808 \\
\hline & $r=1$ & 8,38486 & 5,19275 & 7,86025 & 2,29962 \\
\hline \multirow{2}{*}{ ingapura } & $r=0^{*}$ & 9,18001 & 4,07904 & 6,74481 & 8,58808 \\
\hline & $r=1$ & 2,43520 & 5,19275 & 3,73495 & 2,29962 \\
\hline \multirow{2}{*}{ epang } & $r=0$ & 6,94923 & 4,07904 & 5,88970 & 8,58808 \\
\hline & $r=1$ & 1,05953 & 5,19275 & 2,41379 & 2,29962 \\
\hline
\end{tabular}

Keterangan: *Signifikan pada taraf nyata 5 persen

\section{Analisis Impulse Response Function (IRF)}

Pada penelitian ini, tidak semua IRF dari model yang terbentuk akan dianalisis, melainkan hanya fokus pada respon indikator makroekonomi Indonesia terhadap guncangan pertumbuhan ekonomi mitra dagang utama sebesar satu standar deviasi. Sumbu horizontal dalam IRF menyatakan periode (tahun) setelah terjadi guncangan dan sumbu vertikal menyatakan besarnya respon (persen). IRF disimulasikan sampai dengan periode ke-30 karena pada periode tersebut respon sudah relatif stabil.

\section{Respon Indikator Makroekonomi Indonesia terhadap Guncangan Pertumbuhan Ekonomi Tiongkok}

Berdasarkan Gambar 6, guncangan pertumbuhan ekonomi Tiongkok akan direspon positif oleh indikator makroekonomi Indonesia. Pada tahun pertama, respon pertumbuhan ekspor terhadap guncangan pertumbuhan ekonomi Tiongkok adalah sebesar 1,44 persen, yang berarti ketika pertumbuhan ekonomi Tiongkok mengalami peningkatan sebesar satu standar deviasi 
maka pertumbuhan ekspor Indonesia akan meningkat sebesar 1,44 persen. Demikian pula dengan pertumbuhan PDB dan pertumbuhan penyerapan tenaga kerja yang memberikan respon positif sejak tahun pertama. Pada tahuntahun selanjutnya, respon terus mengalami peningkatan hingga mencapai kondisi keseimbangan. Namun, semakin lama peningkatannya semakin menurun. Pada tahun ke-30, respon ketiga indikator sudah relatif stabil, besarnya respon masing-masing adalah sebagai berikut: pertumbuhan ekspor (23 persen), pertumbuhan PDB (13 persen), dan pertumbuhan penyerapan tenaga kerja (5 persen). Guncangan pertumbuhan ekonomi Tiongkok meninggalkan dampak yang permanen terhadap indikator makroekonomi Indonesia, hal ini dapat dilihat dari respon yang membentuk keseimbangan baru di atas keseimbangan awal.

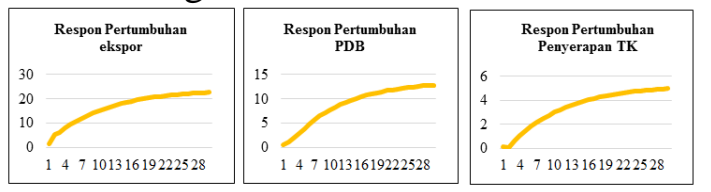

Gambar 6.

Respon indikator makroekonomi Indonesia terhadap guncangan pertumbuhan ekonomi Tiongkok

Respon Indikator Makroekonomi Indonesia terhadap Guncangan Pertumbuhan Ekonomi Singapura

Berdasarkan Gambar 7, pada periode pertama pertumbuhan ekspor dan pertumbuhan PDB memberikan respon positif terhadap guncangan pertumbuhan ekonomi Singapura yakni sebesar 8,68 persen dan 1,34 persen. Sedangkan, pertumbuhan penyerapan tenaga kerja memberikan respon yang negatif, yakni sebesar $-0,02$ persen. Pada tahun-tahun selanjutnya, ketiga respon mengalami peningkatan hingga mencapai angka positif, kemudian bergerak menuju kondisi keseimbangan.
Pada tahun ke-30, respon ketiga indikator sudah relatif stabil, dimana respon pertumbuhan ekspor sebesar 22 persen, pertumbuhan PDB sebesar 12 persen, dan pertumbuhan penyerapan tenaga kerja sebesar 3 persen. Berdasarkan pergerakan IRF, respon indikator makroekonomi Indonesia membentuk keseimbangan baru di atas keseimbangan awal, sehingga dapat dikatakan bahwa guncangan pertumbuhan ekonomi Singapura juga meninggalkan dampak permanen terhadap indikator makroekonomi Indonesia.

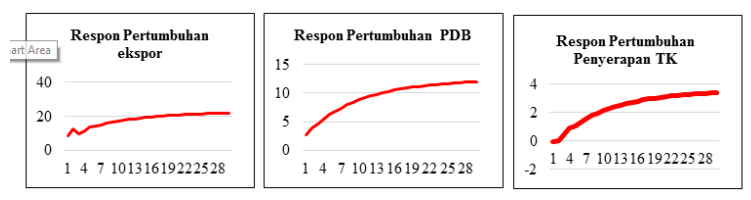

Gambar 7.

Respon indikator makroekonomi Indonesia terhadap guncangan pertumbuhan ekonomi Singapura

Respon $\begin{aligned} & \text { Indikator Makroekonomi } \\ & \text { Indonesia } \\ & \text { terhadap }\end{aligned}$
Pertumbuhan Ekonomi Jepang
Berdasarkan Gambar 8, pada tahun pertama, guncangan pertumbuhan ekonomi Jepang sebesar satu standar deviasi akan direspon positif oleh indikator makroekonomi Indonesia, yakni pertumbuhan ekspor meningkat 6,56 persen, pertumbuhan PDB meningkat 1,34 persen, dan pertumbuhan penyerapan tenaga kerja meningkat 0,42 persen. Pada tahun-tahun selanjutnya, respon ketiga indikator mengalami penurunan hingga mencapai angka negatif selama 2 tahun. Selanjutnya, respon ketiga indikator mangalami peningkatan dan mencapai angka positif. Respon indikator makroekonomi Indonesia berhasil mencapai kondisi keseimbangan awal atau kembali ke nol pada tahun ke-8. Hal ini mengindikasikan bahwa guncangan pertumbuhan ekonomi Jepang berpengaruh terhadap indikator makroekonomi Indonesia hanya sampai tahun ke-8. Sedangkan, dalam jangka 
Jurnal Ilmiah Ekonomi dan Bisnis

Vol. 16. No.1, Maret 2019: 78-92

EISSN : $2442-9813$

ISSN : $1829-9822$

panjang guncangan tersebut tidak lagi berpengaruh.
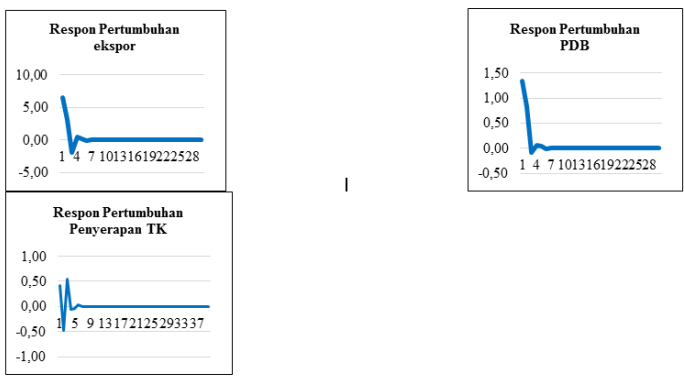

Gambar 8.

Respon indikator makroekonomi Indonesia terhadap guncangan pertumbuhan ekonomi Jepang

Ringkasan Respon Indikator Makroekonomi Indonesia terhadap Guncangan Pertumbuhan Ekonomi Mitra Dagang

Berdasarkan uraian di atas, respon Indikator makroekonomi Indonesia terhadap guncangan pertumbuhan ekonomi ketiga mitra dagang utama adalah positif sesuai dengan yang dihipotesiskan sebelumnya. Hasil penelitian ini sejalan dengan penelitian Bermingham dan Conefrey (2014). Respon positif ini berarti ketika pertumbuhan ekonomi mitra dagang meningkat maka indikator makroekonomi Indonesia juga akan meningkat. Demikian pula sebaliknya, ketika pertumbuhan ekonomi mitra dagang menurun sebagaimana yang terjadi pada beberapa tahun terakhir, maka akan berdampak pada menurunnya indikator makroekonomi Indonesia. Proses transmisi guncangan pertumbuhan ekonomi mitra dagang utama ke perekonomian Indonesia digambarkan dalam Gambar 9 sebagai berikut:

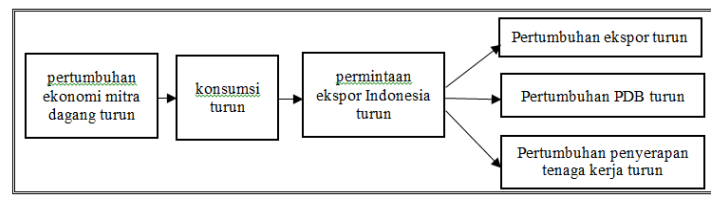

Gambar 9. Transmisi guncangan pertumbuhan ekonomi mitra dagang utama ke indikator makroekonomi Indonesia
Berdasarkan Gambar 9, penurunan pertumbuhan ekonomi yang terjadi pada mitra dagang utama akan diikuti dengan penurunan konsumsi masyarakatnya baik terhadap barang domestik maupun barang impor. Hal ini berdampak pada menurunnya permintaan ekspor Indonesia. Ketika permintaan ekspor mengalami penurunan, pertumbuhan ekspor Indonesia akan menurun. Penurunan permintaan ekspor juga akan berdampak pada menurunnya pertumbuhan PDB Indonesia karena ekspor merupakan salah satu komponen PDB. Selanjutnya, ketika permintaan ekspor menurun, produsen harus mengurangi jumlah produksinya, salah satunya dengan mengurangi input tenaga kerja yang digunakan. Akibatnya pertumbuhan penyerapan tenaga kerja Indonesia akan menurun.

Selanjutnya, untuk mengetahui kekuatan guncangan pertumbuhan ekonomi dari ketiga mitra dagang utama dalam memengaruhi indikator makroekonomi Indonesia dapat dilihat berdasarkan nilai elastisitas responnya. Menurut Bermingham dan Conefrey (2014), elastisitas respon merupakan perbandingan antara akumulasi impulse response variabel penerima guncangan dengan akumulasi impulse response variabel sumber guncangan. Dalam penelitian ini, elastisitas respon dihitung dengan cara membagi akumulasi respon selama 30 tahun dari indikator makroekonomi Indonesia terhadap guncangan pertumbuhan ekonomi mitra dagang utama dibagi dengan akumulasi respon pertumbuhan ekonomi mitra dagang terhadap guncangan dirinya sendiri. Hasil perhitungan elastisitas respon indikator makroekonomi Indonesia untuk ketiga model disajikan dalam Tabel 4. 
Tabel 4. Elastisitas respon indikator makroekonomi Indonesia

\begin{tabular}{|c|l|l|l|}
\hline \multirow{2}{*}{ Elastisitas } & \multicolumn{3}{|c|}{ Guncangan } \\
\cline { 2 - 4 } & Pertumbuhan Ekonomi \\
\hline iongkok & ingapura & epang \\
\hline Pertumbuhan Ekspor &, 0714 &, 1602 &, 0684 \\
\hline Pertumbuhan PDB &, 0380 &, 0833 &, 0181 \\
\hline $\begin{array}{c}\text { Pertumbuhan } \\
\text { penyerapan tenaga kerja }\end{array}$ &, 0146 &, 0210 &, 0034 \\
\hline
\end{tabular}

Nilai elastisitas respon

menunjukkan seberapa besar perubahan indikator makroekonomi Indonesia akibat perubahan pertumbuhan ekonomi mitra dagang sebesar 1 persen. Berdasarkan Tabel 4, indikator makroekonomi Indonesia yang mempunyai elastisitas respon terbesar untuk ketiga model adalah pertumbuhan ekspor. Hasil ini sejalan dengan penelitian sebelumnya dari Bermingham dan Conefrey (2014). Nilai elastisitas yang terbesar tersebut mengindikasikan bahwa guncangan pertumbuhan ekonomi mitra dagang utama berdampak paling besar terhadap ekspor, sehingga dapat dikatakan bahwa ekspor merupakan penghubung utama dari guncangan perdagangan internasional (trade shock) ke perekonomian Indonesia. Sedangkan, indikator yang mempunyai elastisitas respon terkecil adalah pertumbuhan penyerapan tenaga kerja, yang berarti dampak guncangan pertumbuhan ekonomi mitra dagang utama paling kecil diterima oleh pertumbuhan penyerapan tenaga kerja. Hal ini dikarenakan permintaan domestik di Indonesia yang sangat tinggi dan mendominasi (Kiyota, 2014), sehingga kenaikan atau penurunan permintaan ekspor tidak memberikan dampak yang signifikan terhadap penyerapan tenaga kerja.

Dari Tabel 4 tersebut, nilai elastisitas respon pertumbuhan ekspor terhadap guncangan pertumbuhan ekonomi Singapura adalah sebesar 0,1602. Sedangkan, elastisitas respon pertumbuhan ekspor terhadap guncangan dari Tiongkok dan Jepang adalah 0,0714 dan 0,0684. Artinya, kekuatan guncangan pertumbuhan ekonomi Singapura dalam memengaruhi pertumbuhan ekspor Indonesia adalah 2 kali lipat lebih besar dibandingkan dengan guncangan dari Tiongkok dan 2,5 kali lipat lebih besar dibandingkan guncangan dari Jepang. Demikian pula untuk elastisitas respon pertumbuhan PDB dan pertumbuhan penyerapan tenaga kerja, dimana elastisitas respon indikator makroekonomi yang terbesar adalah terhadap guncangan dari Singapura. Hal ini mengindikasikan bahwa guncangan pertumbuhan ekonomi Singapura lebih kuat pengaruhnya terhadap indikator makroekonomi Indonesia dibandingkan dengan guncangan dari Tiongkok ataupun Jepang. Kuatnya pengaruh guncangan pertumbuhan ekonomi Singapura terhadap perekonomian Indonesia didukung oleh banyaknya kerjasama perdagangan regional yang dijalin oleh Indonesia dengan Singapura, seperti AFTA, ACFTA, AIFTA, dan AEC. Selain itu, menurut World Integrated Trade Solution (2015), Indonesia menempati posisi kelima sebagai mitra dagang utama bagi Singapura. Berbeda dengan dua mitra dagang lainnya, yang merupakan mitra dagang utama Indonesia, tetapi Indonesia bukan mitra dagang utama mereka.

\section{Analisis Forecast Error Variance Decomposition (FEVD)}

Pada penelitian ini, analisis dekomposisi varian atau FEVD digunakan untuk melihat seberapa besar kontribusi guncangan pertumbuhan ekonomi mitra dagang dalam menjelaskan variabilitas indikator makroekonomi Indonesia. Simulasi analisis ini diproyeksikan selama 30 periode (tahun), karena pada periode tersebut kontribusi setiap variabel sudah relatif stabil. 
Jurnal Ilmiah Ekonomi dan Bísnis

Vol. 16. No.1, Maret 2019: 78-92

EISSN : $2442-9813$

ISSN : $1829-9822$

Tabel 5. Ringkasan hasil FEVD dari Indikator Makroekonomi Indonesia

\begin{tabular}{|l|l|l|l|l|}
\hline \multirow{2}{*}{$\begin{array}{l}\text { xterna } \\
\text { Shock }\end{array}$} & \multirow{2}{*}{$\begin{array}{l}\text { erio } \\
\text { de }\end{array}$} & $\begin{array}{l}\text { Pertumbuha } \\
\text { n ekspor }\end{array}$ & $\begin{array}{l}\text { Pertumbuhan } \\
\text { ekonomi }\end{array}$ & $\begin{array}{l}\text { Pertumbuhan } \\
\text { penyerapan TK }\end{array}$ \\
\cline { 3 - 5 } $\begin{array}{l}\text { iongk } \\
\text { ok }\end{array}$ & & 1,33 & 2,06 & 2,02 \\
\hline & 0 & 27,60 & 32,91 & 38,62 \\
\hline & 0 & 29,52 & 35,10 & 39,74 \\
\hline ingap & & & & \\
ura & & 53,15 & 42,44 & 17,14 \\
\hline & 0 & 38,17 & 34,72 & 18,08 \\
\hline & 0 & 36,67 & 33,78 & 14,57 \\
\hline epang & & 27,63 & 10,86 & 33,14 \\
\hline & 0 & 32,58 & 13,44 & 33,14 \\
\hline & 0 & 32,58 & 13,44 & \\
\hline
\end{tabular}

Tabel 5 menyajikan ringkasan nilai dekompoisis varian indikator makroekonomi Indonesia dari tahun 1 sampai 30 setelah terjadi guncangan pertumbuhan ekonomi mitra dagang utama. Berdasarkan tabel tersebut, pada tahun pertama, variabilitas pertumbuhan ekspor yang dipengaruhi oleh guncangan pertumbuhan ekonomi Tiongkok adalah sebesar 1,33 persen, sedangkan 98,67 persen lainnya dipengaruhi oleh guncangan pertumbuhan PDB, penyerapan tenaga kerja serta pertumbuhan ekspor itu sendiri.

Kontribusi

guncangan pertumbuhan ekonomi mitra dagang utama terhadap variabilitas indikator makroekonomi Indonesia semakin meningkat seiring dengan meningkatnya periode, kecuali kontribusi guncangan Singapura terhadap variabilitas pertumbuhan ekspor dan PDB yang mengalami penurunan. Sampai dengan tahun ke-30, guncangan pertumbuhan ekonomi Tiongkok dan Jepang mempunyai kontribusi yang paling besar dalam menjelaskan variabilitas pertumbuhan penyerapan tenaga kerja, masing-masing adalah sebesar 39,74 persen dan 33,14 persen pada akhir periode. Sedangkan, guncangan pertumbuhan ekonomi Singapura mempunyai kontribusi paling besar dalam menjelaskan variabilitas pertumbuhan ekspor yakni sebesar 36,67 persen.

\section{KESIMPULAN DAN SARAN}

Berdasarkan hasil dan pembahasan yang telah diuraikan sebelumnya serta merujuk pada tujuan penelitian, maka dapat diambil kesimpulan sebagai berikut:

1. Selama periode 1986-2009, perkembangan pertumbuhan ekonomi mitra dagang utama Indonesia cukup berfluktuasi, tetapi sejak tahun 2010 cenderung menurun. Perkembangan ekspor Indonesia cenderung mengalami peningkatan pada periode 19862011, kemudian menurun pada periode 2011-2015. Sedangkan, perkembangan PDB dan penyerapan tenaga kerja Indonesia cenderung meningkat dari tahun ke tahun.

2. Berdasarkan hasil analisis Impulse Response Function (IRF), respon indikator makroekonomi Indonesia terhadap guncangan pertumbuhan ekonomi mitra dagang utama adalah positif, sehingga guncangan penurunan pertumbuhan ekonomi mitra dagang utama akan berdampak pada menurunnya pertumbuhan ekspor, pertumbuhan PDB, dan pertumbuhan penyerapan tenaga kerja Indonesia. Indikator makroekonomi yang memberikan respon terbesar terhadap guncangan pertumbuhan ekonomi mitra dagang utama adalah ekspor, sehingga dapat dikatakan ekspor merupakan penghubung utama dari guncangan perdagangan internasional (trade shocks) ke perekonomian Indonesia. Guncangan pertumbuhan ekonomi Singapura mempunyai pengaruh yang lebih kuat terhadap indikator makroekonomi Indonesia dibandingkan dengan guncangan dari Tiongkok dan Jepang.

3. Berdasarkan hasil analisis Forecast 
Error Variance Decomposition (FEVD), guncangan pertumbuhan ekonomi mitra dagang utama mempunyai kontribusi yang cukup besar terhadap variabilitas indikator makroekonomi Indonesia.

Berdasarkan hasil penelitian dan kesimpulan yang telah diuraikan sebelumnya, saran yang diajukan oleh penulis adalah sebagai berikut:

1. Untuk meminimalisasi dampak negatif dari guncangan penurunan pertumbuhan ekonomi mitra dagang utama, pemerintah diharapkan memperketat standardisasi produk ekspor dan mendorong peningkatan daya saing produk unggulan ekspor Indonesia agar penurunan ekspor ke mitra dagang dapat ditekan. Selain itu, pemerintah sebaiknya memperluas penetrasi pasar ekspor Indonesia khususnya ke negaranegara yang potensial atau negara yang perekonomiannya masih tumbuh dengan kuat, baik di Asia maupun Afrika.

2. Untuk mengantisipasi penurunan pertumbuhan Produk Domestik Bruto, pemerintah sebaiknya mendorong penguatan pasar domestik karena Indonesia memiliki pangsa pasar yang besar. Usaha yang dapat dilakukan pemerintah diantaranya: memperketat sertifikasi Standar Nasional Indonesia (SNI) untuk membatasi produk impor, meningkatkan kualitas produk domestik, memberikan insentif kepada para pelaku usaha, dan mempermudah perizinan usaha.

3. Untuk mengantisipasi penurunan penyerapan tenaga kerja, pemerintah diharapkan mengoptimalkan peran Lembaga Pembiayaan Ekspor Indonesia
(LPEI) dalam pembiayaan, penjaminan, dan asuransi ekspor, khususnya untuk Usaha Kecil Menengah (UKM) yang berorietasi ekspor dan industri pada karya.

Untuk penelitian selanjutnya, penelitian ini bisa dikembangkan dengan menambahkan guncangan eksternal dari mitra dagang lainnya, seperti Amerika Serikat dan Korea Selatan, karena ekspor Indonesia ke dua negara tersebut cukup besar atau dengan menambahkan variabel inflasi (IHK), nilai tukar, dan suku bunga sebagai variabel penerima guncangan.

\section{DAFTAR PUSTAKA}

Badan Pusat Statistik. Diakses pada tanggal 8 November 2016 melalui https://www.bps.go.id/

Bermingham, Colin dan Thomas Conefrey. (2014). The Irish Macroenomic Response to an External Shock with an Application to Stress Testing. Journal of Policy Modeling, 1-17.

Bounchaour dan Hussein. (2012). Oil Price Distorsion and Their Impact on Algerian Macroeoconomic. International Journal of Business and Management, 7 (18), 9-114.

Enders, Walter. (2004). Applied Econometric Time Series Second Edition. USA: John Wiley \& Sons, Inc Gujarati, Damodar N. (2004). Basic Econometrics fourth edition. New York: McGraw-Hill Companies, Inc.

Gujarati, Damodar N. (2004). Basic Econometrics fourth edition. New York: McGraw-Hill Companies, Inc.

Kiyota, Kozo. (2014). Export and Employment in China, Indonesia, 
Jurnal Ilmiah Ekonomi dan Bísnis

Vol. 16. No.1, Maret 2019: 78-92

EISSN : $2442-9813$

ISSN : $1829-9822$

Japan and Korea. OECD Trade Policy Paper No.166.

Lutkepohl, Pentti, dan Carten. (2002). Maximum Eigenvalue Trace Test for the Cointegrating Rank of a VAR Process. Economoetric Journal, 1-29.

Lutkepohl, Helmut. (2005). New Introduction to Multiple Time Series Analysis. New York: Springer Herlin Heidelberg.

Nizar, Muhammad Afdi. (2012). Dampak Fluktuasi Harga Minyak Dunia terhadap Perekonomian Indonesia. Buletin Ilmiah Litbang Perdagangan, 6 (2), 189 210.

Ramana, Febria. (2016). Contagion Effect Perekonomian Amerika Serikat dan Cina Terhadap perekonomian Indonesia [Skripsi]. Jakarta: Sekolah Tinggi Ilmu Statistik.

Retnasih, Agustin, dan Wulandari. (2016). Analisis Guncangan Eksternal Terhadap Indikator Moneter dan Makro Indonesia. Jurnal Ekonomi dan Studi Pembangunan, 8(2).

Sato, Zhang, dan McAleer. (2011). Identifying Shock in Regionally Integrated East Asian Economics with Structural VAR and Block Exogeneity. Mathematics and Computers in Simulation, 81.

Setiawan, Wawan. (2010). Analisis Dampak Fluktuasi Perekonomian Dunia Terhadap Efektivitas Kebijakan Moneter [Tesis]. Depok: Universitas Indonesia.
Tambunan, T. (2010). The Indonesian Experience with Two Big Economy Crises. Modern Economy, 1, hal. 156-167.

World Bank. (2016). Diakses pada tanggal 20 Januari 2017 melalui http://data.worldbank.org

World Integrated Trade Solution. (2015). Diakses pada tanggal 10 Juni 2017 melalui http://wits.worldbank.org

Zamrowi, M. Taufik. (2007). Analisis Penyerapan Tenaga Kerja Pada Industri Kecil (Studi di Industri Kecil Mebel di Kota Semarang) [Tesis]. Semarang: Universitas Diponegoro. 